Artigo / Article

\title{
Angiotensin converting enzyme (ACE) DD genotype: relationship with venous thrombosis
}

\author{
Genótipo DD da enzima conversora de angiotensina (ECA): relação com trombose venosa
}

Terezinha P. Munhoz $z^{1,2,3}$

Rosane M. Scheibe ${ }^{1,2}$

Virgínia M. Schmitt ${ }^{1,2}$
Venous thromboembolism is a common multifactorial disease associated with acquired and inherited predisposing factors. Several polymorphisms, e.g. factor V Leiden, factor II G20210A and deficiency of antithrombin, protein C and protein $S$, have been associated with venous thromboembolism. Angiotensin converting-enzyme affects hemostasis by decreasing fibrinolysis. Angiotensin converting-enzyme gene polymorphism, a $287 \mathrm{pb}$ insertion/deletion at introns 16 , is related to variations in enzyme serum levels. The DD genotype has been associated with increased risk for venous thrombosis. This study examined the frequency of the angiotensin converting-enzyme alleles I and D and their association with venous thrombosis in a group of individuals from the south of Brazil. Seventy-one patients with deep venous thrombosis and/or pulmonary thromboembolism and 71 healthy individuals were analysed in a case-control study. The angiotensin converting-enzyme ID genotyping was performed by polymerase chain reaction. The frequencies of the D allele and DD genotype were, respectively, $51.4 \%$ and $22.5 \%$ for patients, and $64.7 \%$ and $45.0 \%$ for controls. The Odds Ratio for the dominant hypothesis (DD+ID versus II genotypes) was 0.75 (CI 95\%; 0.29-1.93) and the Odds Ratio for recessive hypothesis (DD versus $I D+I I)$ was 0.35 (CI 95\%; 0.16-0.78). In conclusion, our results indicate a protective effect of the angiotensin converting-enzyme DD genotype on venous thromboembolism. Rev. bras. hematol. hemoter. 2005;27(2):87-90.

Key words: ACE; fibrinolysis; venous thromboembolism.

\section{Introduction}

Venous thromboembolism (VTE) is a widespread multifactorial disease associated to inherited and acquired predisposing factors such as advanced age, prolonged immobilization, surgery, malignancies, antiphospholipid syndrome, oral contraceptives and hormone replacement therapy. Most polymorphisms associated to VTE lie preferentially or predominantly in genes encoding coagulant and anticoagulant proteins and include the mutations factor V Leiden, factor II (G20210A) and in genes encoding antithrombin, protein $\mathrm{C}$ and protein $\mathrm{S} .^{1}$
The renin-angiotensin system (RAS) is a complex regulator of blood pressure, water homeostasis, cardiovascular remodeling and vascular tone. This system is composed of several key proteins including angiotensinogen, angiotensin converting enzyme (ACE) and angiotensin II and its receptors affect hemostasis through different mechanisms. ${ }^{2}$ The fibrinolytic system constitutes the endogenous defense mechanisms against intravascular thrombus formation and is activated by the presence of a fibrin clot within the vasculature. Fibrinolysis starts when plasminogen, mediated by activators, is converted to plasmin, a proteolytic enzyme. ${ }^{3}$ Two important plasminogen activators

\footnotetext{
${ }^{1}$ Instituto de Pesquisas Biomédicas.

${ }_{3}^{2}$ Faculdade de Farmácia.

${ }^{3}$ Laboratório de Patologia Clínica do Hospital São Lucas da Pontifícia Universidade Católica do Rio Grande do Sul - Porto Alegre-RS, Brasil.

Laboratório de Biologia Molecular do Instituto de Pesquisas Biomédicas da PUC do Rio Grande do Sul, Porto Alegre-RS, Brasil.
}

Corresponding author: Terezinha P. Munhoz

Hospital São Lucas - PUCRS

Av Ipiranga, 6690

90610-000 - Porto Alegre-RS - Brazil

Tel.: 5551 3320-31-45-E-mail: tpazm@pucrs.br 
in the vascular system are tissue-type plasminogen activator (t-PA) and urokinase (u-PA). Fibrinolysis is regulated by the balance between the activity of plasminogen activators and their inhibitors. Plasminogen activator inhibitor type 1 (PAI-1) is the most important physiologic inhibitor of t-PA and urokinase in plasma. ${ }^{4}$ Clinical and experimental studies have defined the relationship between RAS and the fibrinolytic system. ${ }^{3-6}$ Angiotensin I is converted to angiotensin II by ACE which binds to endothelial cells and stimulates the production of plasminogen activator inhibitor type I (PAI-1) thus down-regulating fibrinolysis. In addition, ACE degrades bradykinin, an important mediator of the tissuetype plasminogen activator (t-PA), which also contributes to decrease fibrinolysis, hence increasing the thrombotic risk. ${ }^{4}$

Polymorphism of gene encoding components of RAS, angiotensinogen, $\mathrm{ACE}$ and angiotensin I receptors have been associated to hypertension and myocardial infarction..$^{7-9}$ Recent studies have suggested the involvement of some polymorphisms in RAS genes in the pathogenesis of VTE. ${ }^{10,11}$ The ACE gene polymorphism was first reported by Rigat et al, consisting of the presence (insertion-I) or absence (deletion-D) of a $287 \mathrm{pb}$ fragment, at the angiotensin I converting enzyme gene (introns 16). Three genotypes can result: II, DD and ID. Their study also showed that the D allele was associated with increased serum levels of circulating enzyme. ${ }^{12}$

Despite the fact that most studies concerning the pathophysiologic effects of the RAS have been confined to the arterial vasculature, increasing evidence indicates that the venous system may also be affected by changes in RAS genes and its association with fibrinolysis. ${ }^{2}$

Previous studies have investigated the polymorphism ID of the ACE gene as a risk factor for venous thrombosis, reporting conflicting data. ${ }^{10,17}$ The aim of this study was to determine the frequency of allele I and D in patients with VTE and investigate its association to venous thromboembolism.

\section{Subjects and Methods}

\section{Patients and controls}

This case-control study was conducted at Hospital São Lucas of Pontifícia Universidade Católica do Rio Grande do Sul (Porto Alegre, Brazil) from May 2001 to December 2003. Cases were recruited among patients attending the Cardiovascular Surgery or Hematology Ambulatory, and inpatients from the Coronary Treatment Unit. To participate in this study, patients should have suffered at least one confirmed episode of deep venous thrombosis and/or pulmonary thromboembolism. The VT diagnosis was confirmed by doppler ultrasound and PE by scan pulmonary angiography. Control subjects were recruited among Genesis Project participants (a cohort study of the Institute of Geriatrics and Gerontology PUCRS), with no history of thrombosis, and according to patients' age, ethnicity and gender. Written informed consent was obtained from all cases and controls. This protocol was approved by the Ethics Committee for Research of the University. Patients were excluded in cases of malignant disorder, antiphospholipid syndrome or surgery.

\section{Genotyping}

Blood samples $(5 \mathrm{~mL})$ were collected in EDTA-K3 Vacutainer tubes. DNA was extracted using GFX Genomic kit (Amersham Pharmacia Biotec Inc) according to the manufacturer's instructions. The insertion/deletion genotyping was performed by polymerase chain reaction (PCR), according to Rigat et al, ${ }^{18}$ modified by Ueda et al. ${ }^{19}$ The reaction mixture $(25 \mathrm{~L})$ contained 20 pmol of each primer (Life Technologies, USA), 2 mM MgCl2, 200 mM dNTP mix (Life Technologies, USA), 1\% DMSO, 1.75 U Taq DNA polymerase (Life Technologies, USA), $2 \mathrm{mM}$ Tris-HCl pH 8.4 and $5 \mathrm{mM} \mathrm{Kcl}$. The amplification program was $94^{\circ} \mathrm{C} / 3 \mathrm{~min} ; 30$ cycles of $\left[94^{\circ} \mathrm{C} / 1 \mathrm{~min}, 52^{\circ} \mathrm{C} / 1 \mathrm{~min}, 72^{\circ} \mathrm{C} / 1 \mathrm{~min}\right]$ and $72^{\circ} \mathrm{C} / 5 \mathrm{~min}$. PCR products were electrophoresed in $2 \%$ agarose gel containing ethidium bromide and analysed under UV light. Primer sequences and product sizes are shown in Table 1.

\section{Statistical analysis}

Statistical analysis was performed with EPI Info 6.0. The ACE allele and genotypic frequencies were obtained by direct count. The genotype distribution and allele frequencies were compared using the chi-square test. Odds ratio was estimated with a $95 \%$ confidence interval as a measure of risk. All statistics tests were two sided and a P value $<0.05$ was considered significant.

Table 1

Primers sequence and PCR product sizes for ACE genotyping

\begin{tabular}{|c|c|c|c|}
\hline & \multirow{2}{*}{ Primer sequence } & \multicolumn{2}{|c|}{ Product size $(b p)$} \\
\hline & & $\mathrm{D}$ allele & I allele \\
\hline Forward $^{1}$ & 5'-CTGGAGACCACTCCCATCCTTTCT-3' & \multirow{2}{*}{190} & \multirow{2}{*}{480} \\
\hline Reverse $^{1}$ & 5'-GATGTGGCCATCACATTCGTCAGAT-3' & & \\
\hline Internal $^{2}$ & 5'-TGGGATTACAGGCGTGATACAG-3' & - & 160 \\
\hline
\end{tabular}

\section{Results}

DNA was analysed for ACE genotypes from venous blood of 71 patients and 71 controls, 32 men (45.1\%) and 39 $(54.9 \%)$ women in each group. Mean age of patients was 51.2 years and for controls it was 51.7. Among patients, 46 had suffered only one episode, 25 were recurrent, 48 were DVT cases and $23 \mathrm{PE}$. The frequencies of the $\mathrm{D}$ allele were $51.4 \%$ 
for patients and $64.7 \%$ for controls. For the DD genotype, the frequencies were $22.5 \%$ for patients and $45.0 \%$ for controls. The OR for the dominant hypothesis (DD + ID versus II genotypes) was 0.75 (CI 95\%; 0.29-1.93) and for recessive hypothesis (DD versus ID + II) was 0.35 (CI 95\%; 0.16-0.78). The ACE genotyping distribution and allele D frequencies and risk associated with gender for patients and controls are shown in Tables 2 and 3.

\begin{tabular}{cccc}
\multicolumn{5}{c}{ Table 2 } \\
& ACE genotyping distribution \\
\hline & $\begin{array}{c}\text { VTE patients } \\
\mathrm{n}(\%)\end{array}$ & $\begin{array}{c}\text { Controls } \\
\mathrm{n}(\%)\end{array}$ \\
\hline ACE & DD & $16(22.5)$ & $32(45.0)$ \\
genotype & ID & $41(57.7)$ & $28(39.6)$ \\
& II & $14(19.7)$ & $11(15.4)$ \\
\hline
\end{tabular}

ACE: angiotensin converting enzyme; D: Deletion; I: Insertion
2.8), but no increased risk for women patients..$^{11}$ No correlation between ACE genotype and venous thrombosis was found by Ordoñez et al in a study conducted with patients under coumarin therapy from a Caucasian population in the north of Spain. ${ }^{13}$ Jackson et al, in another case-control study conducted of more than 500 unselected patients, the ID polymorphism in the ACE gene was not a risk factor for venous thromboembolism. ${ }^{14}$ Della Valle et al, analysed the genetic profiles of 38 patients who had a postoperative symptomatic pulmonary embolus or proximal deep venous thrombosis following a joint arthroplasty and 241 control subjects, without thrombosis. No difference was observed between both groups. These results suggest that there is no association between the presence of the $\mathrm{D}$ allele and increased risk of symptomatic thromboembolic events following total hip or knee arthroplasty. ${ }^{15}$ In contrast, it was reported by Philip et al. that the deletion polymorphism of ACE gene is a significant risk factor for venous thrombosis following hip replacement surgery. The homozygous DD genotype increased the thrombotic risk more than 11-fold (OR 11.7 CI 95\% 2.3-84.5), and heterozygous ID genotype increased the risk approximately 5 -fold. ${ }^{10}$ It is important to point out that the study of Phillip et al was conducted with postoperative patients and there is a known influence of endothelial damage induced by orthopedic surgery in the pathogenesis of thrombosis, which may interfere in the analysis of genetic risk factors. On the other hand, patients studied by Della Valle, also underwent hip surgery and no association was found.

Recently, Fatini et al showed a significant association between ACE DD genotype and venous thromboembolism adjusted for acquired and hemostasis risk factors $(\mathrm{p}<0.0001)$. This study included 336 patients, $40 \%$ idiopathic VTE and $60 \%$ secondary VTE. They concluded that ACE DD genotype increases the risk of venous

\section{Discussion}

The interaction of RAS with hemostasis components common to venous and arterial diseases suggests a relationship of genetic polymorphisms, the coagulation system and VTE. ACE is related to hypofibrinolysis by both increasing the PAI-1 expression and decreasing t-PA production.

In the present study, $22.5 \%$ of cases and $45 \%$ of controls have the ACE DD genotype. The overall OR for the dominant hypothesis (DD + ID versus II genotypes) was 0.75 (CI 95\%; $0.29-1.23 ; \mathrm{P}=0.51)$ and it was 0.35 for the recessive hypothesis (DD versus ID +II) $(\mathrm{CI} 95 \% ; 0.16-0.78 ; \mathrm{P}=0.004)$. This finding suggests a protective effect of the ACE DD genotype on VTE.

Dilley et al, studying African-Americans with venous thrombosis demonstrated a moderate increase of venous thrombosis risk in male patients with the DD genotype (OR thromboembolism in subjects apparently without predisposing factors and thrombophilic alterations, and in subjects in whom a thrombogenic condition occurs. ${ }^{16}$ In contrast, Wells et al, in a case-control study that prospectively enrolled consecutive patients with at least one objectively confirmed idiopathic VTE $(n=300)$, concluded that the ACE DD genotype is protective against idiopathic venous thromboembolism $(0.66) .^{17}$

Results of publications on the relationship of ACE ID genotype and VTE presented above are contradictory and some limitations (e.g., the broad spectrum of patients enrolled) are found. Most of all, they evaluate groups of patients with different profiles, therefore a comparative analysis of the reported results would be hard to perform. Our study was similar to, and indeed in accordance with, the study devised by Wells et al., both excluding VTE patients with malignancy, surgery, and antiphospholipid syndrome. This represented a 
limiting factor and accounted for our restricted sample size. Individuals from the control group were selected among a healthy population from the same geographic area of patients, according to patients' age, ethnicity and gender. We consider those a more suitable control group, once their medical history excluded any thrombotic event. It is important to point out that most of our patients were Caucasian and so probably our results do not apply to other racial groups.

In conclusion, our results suggest that the ACE DD genotype do not represent a risk factor for venous thrombosis and may exert a protective effect on VTE. Further studies are needed, possibly conducted with an extended population, in order to confirm our findings.

\section{Acknowledgements}

We wish to acknowledge the Hematology and Cardiovascular Surgery Departments and the Coronary Treatment Unit of Hospital São Lucas (PUCRS). We also thank the staff and students of the Molecular Biology Laboratory (IPB-PUCRS) for their technical assistance.

\section{Resumo}

O troemboembolismo venoso (TEV) é uma doença multifatorial associada com fatores de risco adquiridos e hereditários. Vários polimorfismos, tais como fator $V$ de Leiden, mutação G20210A da protrombina e as deficiências de proteina $C$, proteina Se antitrombina são considerados fatores de risco para TEV. A enzima conversora da angiotensina (ECA) afeta a hemostasia diminuindo a fibrinólise. $O$ polimorfismo no gene da ECA, caracterizado pela inserção/deleção de um fragmento de $287 \mathrm{pb}$ no intron 16 , está relacionado a variações nos níveis séricos da enzima. O genótipo DD foi associado com aumento de risco para TEV. Este estudo examinou a freqüencia dos alelos I e D e a sua associação com trombose venosa em um grupo de indivíduos do Sul do Brasil. Foram analisados 71 pacientes com trombose venosa profunda elou tromboembolismo pulmonar e 71 indivíduos sem história de trombose. A genotipagem foi realizada através da reação em cadeia da polimerase. As freqüencias do alelo De do genótipo DD foram, respectivamente, 51,4\% e 22,5\% para os pacientes, e $64,7 \%$ e 45,0\% para os controles. A razão de chance (odds ratio $=O R$ ) para a hipótese dominante (genótipos $D D+I D$ versus genótipo II) foi 0,75 (IC 95\%;0,29-1,93) e a OR para a hipótese recessiva (genótipo $D D$ versus genótipos $I D+I I)$ foi 0,35 (IC $95 \% ; 0,16-0,78)$. Concluindo, nossos resultados sugerem que o genótipo DD não representa um fator de risco para TEV e pode exercer um efeito protetor para trombose venosa. Rev. bras. hematol. hemoter. 2005; 27(2):87-90.

Palavras-chave: ECA; fibrinólise; tromboembolismo venoso.

\section{References}

1. Franco RF, Reitsma PH. Genetic risk factors of venous thrombosis. Hum Genet 2001;109:369-84.

2. Hooper CW, Dowling NF, Wenger NK, et al. Relationship of venous thromboembolism and myocardial infarction with the reninangiotensin system in African-Americans. Am J Hematol 2002; $70: 1-8$.
3. Brown NJ, Vaughan DE. The renin-angiotensin and fibrinolytic systems. Co-inspirators in the pathogenesis of ischemic cardiovascular disease. TCM 1996;6(7):239-43.

4. Vaughan DE. The renin-angiotensin system and fibrinolysis. Am J Cardiol 1997;79(5A):12-16.

5. Ridker PM, Gaboury CL, Conlin PR, et al. Stimulation of plasminogen activator inhibitor in vivo by infusion of angiotensin II: evidence of a potential interaction between the renin-angiotensin system and fibrinolytic function. Circul 1993;87: 1.969-73.

6. van Leeuwen RTJ, Koll A, Andreotti F, et al. Angiotensin II increases plasminogen activator inhibitor type 1 and tissue-plasminogen activator messenger RNA in cultured rat aortic smooth muscle cells. Circul 1994;90:362-8.

7. Dzau VJ. Cell biology and genetics of angiotensin in cardiovascular disease. J Hypertens 1994;(S)S3-S10.

8. Katsuya T, Koike G, Yee TW, et al. Association of angiotensinogen gene T235 variant with increased risk of coronary heart disease. Lancet 1995;345:1600-3.

9. Cambien F, Costerousse O, Tiret L, et al. Plasma level and gene polymorphism of angiotensin-converting enzyme in relation to myocardial infarction. Circul 1994;90:669-76.

10. Philipp CS, Dilley A, Saidi P, et al. Deletion polymorphism in the angiotensin-converting enzyme gene as a thrombophilic risk factor after hip arthroplasty. Thromb Haemost 1998; 80:869-73.

11. Dilley A, Austin H, Hooper WC, et al. Relation of three genetic traits to venous thrombosis in an african-american population Am J Epidem 1998;147:30-5.

12. Rigat B, Hubert C, Alhenec-Gelas F, et al. An insertion/deletion polymorphism in the angiotensin I-converting enzyme gene accounting for half the variance of serum enzyme levels. J Clin Invest 1990;86(4):1343-6.

13. González Ordoñez AJG, Carreira JMF, Rodríguez JMM, et al. Risk of venous thromboembolism associated with the insertion/deletion polymorphism in the angiotensin-converting enzyme gene. Blood Coag Fbrin 2000;11:485-90.

14. Jackson A, Brown K, Langdown J, et al. Effect of angiotensinconverting enzyme gene deletion polymorphism on the risk of venous thromboembolism. Br J Haem 2000;111:562-4.

15. Della Valle JC, Issack PS, Baitner A, et al. The relationship of the factor $\mathrm{V}$ Leiden mutation or the deletion polymorphism of the angiotensin converting enzyme to postoperative thromboembolic events following total joint arthroplasty. Muscul Dis 2001;2:1.

16. Fatini C, Gensini F, Sticchi E, et al. ACE DD genotype: an independent predisposition factor to venous thromboembolism. Eur J Clin Invest 2003;33:642-7.

17. Wells PS, Rodger MA, Forgie MA, et al. The ACE DD genotype is protective against the development of idiopathic deep vein thrombosis and pulmonary embolism. Thromb Haemost 2003; 90:829-34.

18. Rigat B, Hubert C, Corvol P, et al. PCR detection of the polymorphism of the human angiotensin converting enzyme gene (DCP1 (dipeptidyl carboxypeptidase 1) Nucl Ac Res 1992;20 (6):1.433.

19. Ueda S, Heeley RP, Lees KR, et al. Mistyping of the human angiotensinconverting enzyme gene polymorphism: frequency, causes and possible methods to avoid errors in typing. J Mol Endoc. 1992;17:27-30.

Financial support: This work was partially supported by Fundação de Amparo à Pesquisa do Rio Grande do Sul (FAPERGS) and Pontificia Universidade Católica do Rio Grande do Sul (PUCRS).

Avaliação: Editor e dois revisores externos.

Conflito de interesse: não declarado

Recebido: 30/05/2005

Aceito após modificações: 10/06/2005 